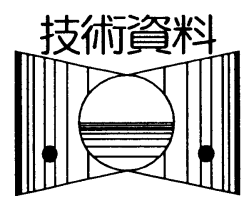

\title{
植物油を使用する直噴式高速ディーゼル 機関の特徵と性能*
}

孫平** 岡田博**

Characteristics and Performances of High Speed Direct Injection Diesel Engine Running on Vegetable Oil

By Ping Sun, Hiroshi Okada

There have been much interest in the use of vegetable oils as diesel fuel since they are renewable energy source and the $\mathrm{CO}_{2}$ emission is low. This paper describes the development of a diesel engine running on rape seed oil.The influences of fuel properties on engine combustion and the adaptability of combustion system to fuel are analyzed.The characteristics and performances of a new high speed multifuel direct injection diesel engine are explained in detail.

\section{1. まえがき}

石油資源の減少に従って，内燃機関用燃料とし て特定のエネルギー源への依存度が低下し, 将来 の燃料多様化に向けていろいろな代替燃料が検討 されている。その中で，再生可能な植物油をディ 一ゼル機関の代替燃料油として利用することは, 二酸化炭素 $\left(\mathrm{CO}_{2}\right)$ の排出濃度が少なく, 自然循 環が確立されるなど他のエネルギー源にはない大 きな利点を持っている。しかし, 植物油の高粘度 あるいは低揮発性に起因する機関性能と耐久性, 排気エミッションや炭素状物質の堆積などに関す る問題があり,これらの問題を改善して, 植物油 を有効利用することを目的とした研究が進んでい る. ${ }^{[1]}$ 植物油を使用すれば, 機関動力性能と効率 は変化せずに, 排気エミッションと耐久性が悪化 することが云われている。水と植物油を混合した 乳化燃料油を使用することにより，シリンダー内 噴霧特性と燃焼性を改善し，末燃焼成分を少なく し，燃料消費率が低減するという報告もあるが， 炭素状物質の堆積などの問題がある。さらに，副

*原稿受付 平成 10 年 5 月 11 日

**正会員 東京商船大学（江東区越中島2-1-6)
室式燃焼室と大型ディーゼル機関は直接噴射式高 速ディーゼル機関より植物油に対する適応性があ ると云われている．植物油を使用することによる， 機関性能と耐久性は機関の構造によって決まるよ うである.

ここでは高速ディーゼル機関の燃料噴射や燃焼 室の構造の特徵及び菜種燃料油に対する適応性を 分析し，機関に菜種燃料油を使用した場合の性能 を調べた。

\section{2. 供試燃料の性状およびディーゼル機関への 適応性}

実験に使用した菜種油と軽油の性状を表 1 に示 す。菜種油は軽油と物性が似ているため, 機関に 使用した場合の着火性能, 燃焼性能および排気力 スの特性も似たものになると考えられる。菜種油 を使用すれば，機関性能が以下のようになると推 察される。

1）菜種油の低位発熱量は軽油より $10 \%$ 低いも のの, 密度が軽油より $10 \%$ 高いので，1サイクル 当たりの体積給油量が同じとすれば，サイクル発 熱量がほぼ同一で, 機関の出力, トルクの差異が 少ない。 


\section{Table1 Fuel properties}

\begin{tabular}{|l|c|c|}
\hline Properties & $\begin{array}{c}\text { Diesel } \\
\text { fuel }\end{array}$ & $\begin{array}{c}\text { Rape seed } \\
\text { oil }\end{array}$ \\
\hline Cetane number & 50 & 41 \\
\hline Density@15 $\mathrm{C}\left[\mathrm{g} / \mathrm{cm}^{3}\right]$ & 0.84 & 0.916 \\
\hline Calorific value $[\mathrm{MJ} / \mathrm{kg}]$ & 42.7 & 36.7 \\
\hline Viscosity@20 ${ }^{\circ} \mathrm{C}\left[\mathrm{mm}^{2} / 8\right]$ & 4.7 & 75 \\
\hline C:H:O & $87: 13: 0$ & $78: 11: 11$ \\
\hline Distillation [ $\left[{ }^{\circ} \mathrm{C}\right]$ & & \\
$10 \%$ Vol & 210 & 305 \\
$50 \%$ Vol & 260 & 330 \\
$90 \%$ Vol & 345 & 350 \\
Boiling end & 350 & 350 \\
\hline Flash point $\left[{ }^{\circ} \mathrm{C}\right]$ & 69 & 246 \\
\hline Cloud point $\left[{ }^{\circ} \mathrm{C}\right]$ & -15 & -3.9 \\
\hline Sulphur $[\%]$ & 0.2 & 0.001 \\
\hline
\end{tabular}

2) 菜種油は酸素を含む燃料で, 軽油より着火 性能は低いものの，一旦着火すれば，酸素を自己 供給する効果があるため，燃焼速度が速い，結果 として，スモーク排出量が少なくなる.

3）菜種油は任意の比率で軽油と混合でき，互 いに溶解し合う。混合油は長年にわたって保存し ても分離しない，したがって，任意の混合比率を 持つ混合油を機関に使用でき，給油や運転操作の 上で便利である。

以上のような利点に対して, 菜種油は軽油より 粘度が高く，七タン価と揮発性が低く，残留炭化 物が多いなどの特徴があるので, 高速ディーゼル 機関に植物油を使用すれば，以下の問題点が生じ るであろう。

1）菜種油はセタン価と低温留出分濃度が低い ため，低温始動が難しい。

2) 菜種油を燃焼させると, 燃料分子の熱分解 及び燃焼により，燃焼室，ピストン，燃料噴射弁 とピストンリングなどの各所に炭化物の付着蓄積 及び焦げ付きが生じるため, 磨耗の増大, 機械効 率の低下，ピストンリングの膠着さらにノズル噴 口の詰まりなどが問題になる.

3）低温始動の際に, 菜種油の未燃焼又は不完 全燃焼により，菜種油がシリンダー壁に沿ってク ランク室に入り，潤滑油に混入し，潤滑油の粘度 が低下するため, 直噴式高速ディーゼル機関の耐 久性が悪化する。

以上の問題点を解決するために, 菜種油の処理 によって, 燃料油の性状を改善する, 一方で機関 の構造を改良する必要もある。高速ディーゼル機 関の燃焼系は副室式と直噴式の 2 種類がある。植
物油を使用すれば, 副室式（予燃焼室式と過流室 式など）機関では，噴射并の多くは自浄効果を持 つピントル・ノズルなので, 炭化物の付着蓄積及 び焦げ付きが生じにくく，噴口の詰まりからの噴 射特性の悪化が少ない。更に, 副室内での高温壁 面と高速空気流動によって, 菜種油の燃焼性能を 保全できるため, 良好な機関性能と耐久性が得ら れる. 副室式機関と直接噴射式機関と, 気筒直径 の大きいものが小さいものより，植物油を使用し たときの性能と耐久性が良いと云われている，直 噴式高速ディーゼル機関は副室式より低温始動が し易く，燃料消費率が低いが，植物油を使用すれ ば，ホールノズルの炭化物の付着蓄積とノズル噴 口が詰まるため噴霧特性と燃焼性が悪化する。ピ ストン上へ直接噴射された菜種油の未燃焼部分の 熱分解ため, 燃焼室とピストンリング溝で炭化物 の付着蓄積及びピストンリングの膠着が生じ易い. さらに, クランク室に入る菜種油が潤滑油を污染 し, 機関性能と耐久性を悪化する。従って, 直噴 式高速ディーゼル機関を植物油により運転するた めに，低温始動，炭化物の付着蓄積及び焦げ付き， 潤滑油の希釈などの問題を解決するため, 新しい 直噴式ディーゼル機関の開発が必要である。

\section{3. 新しい直噴式高速ディーゼル機関の 構造特徴}

直噴式高速ディーゼル機関を植物油により運転 するために，機関の燃焼系などの構造を変更した 新しい機関の上部構造の断面を図 1 に示す。この供 試機関は 3 気筒, 過給器付き, 油冷却, 4 サイクル 直噴式高速ディーゼル機関である．表2にはこの機 関の主要諸元を示す. ${ }^{[2]} こ の$ 機関構造の特徵は次 のようである。

1）燃料噴射系について 軽油と植物油それ ぞれに給油ポンプを設けて，始動時及び停止直前 時は軽油を使用し，定常運転時は植物油を使用す る。低温始動するときの燃焼不完全と炭化物の付 着蓄積を防止でき, 停止しているとき, 機内菜種 油がなく，潤滑油を污染しない. 1シリンダーずつ 噴射ポンプとピントルノズルを有する。燃料噴射 系の高圧容積が小さく，異常噴射がなく，ノズル 自浄効果を有するので，ノズルに炭化物の付着蓄 積及び焦げ付き，噴口の詰まる現象を防止できる。 


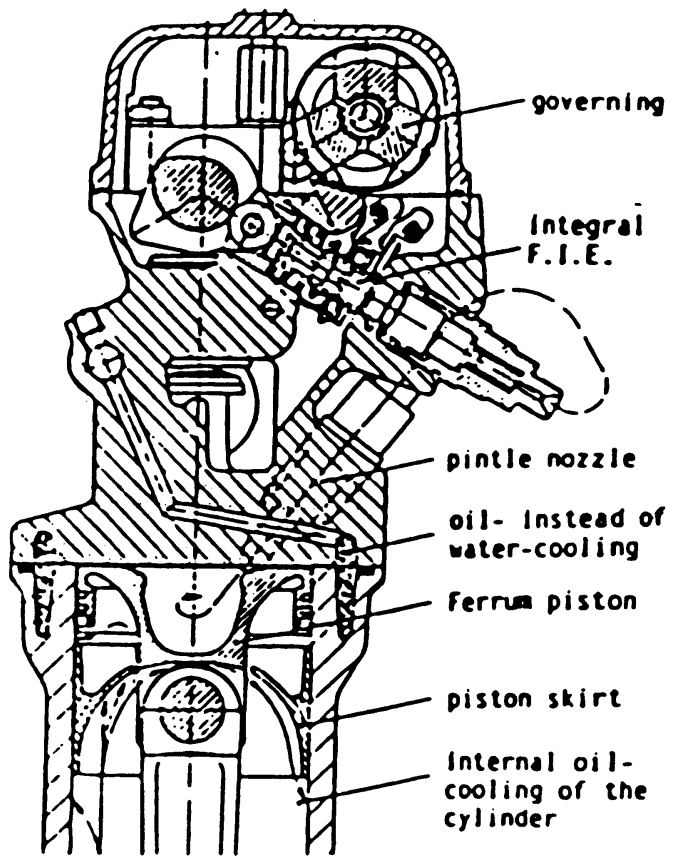

Fig.1 382TC diesel engine

Table2 Engine parameters

\begin{tabular}{|c|c|}
\hline Bore $\times$ Stroke $(\mathrm{mm})$ & $82 \times 90$ \\
\hline Cylinder number & 3 \\
\hline Compression ratio & $18: 1$ \\
\hline Rated power/speed & $62 \mathrm{kw} / 4300 \mathrm{rpm}$ \\
\hline Max. torque/speed & $155 \mathrm{Nm} / 3000 \mathrm{rpm}$ \\
\hline Weight(kg) & $137 \mathrm{~kg}$ \\
\hline Combustion chamber & DI \\
\hline Fuels & Diesel/Vegetable \\
\hline Cooling method & Oil-cooling \\
\hline
\end{tabular}

菜種油はシリンダーヘッドにある通路を経て，加 熱されて，粘度を低減されるため，良好な噴霧特 性が得られる。

2）燃焼系についてこの機関は, 空気過給, ヘリカルポートと球形燃焼室によって, 燃焼室中 に強い空気運動が形成される。ノズル噴口は空気 流動速度が最も速い部分に位置しており，燃料は 気流と同じ方向に燃焼室の中心へ噴射され，噴霧 はスワール空気層に包まれて，壁面には接触しな いようにする，罒2のような燃焼方式によって，燃 焼室内に炭化物の付着蓄積を防止できる。

3）両片連接ピストンについて 断熱性が高

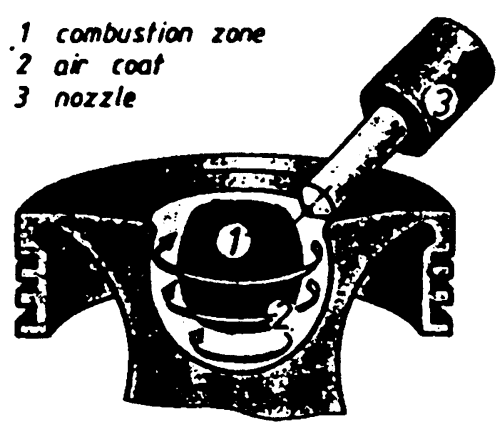

Fig.2 Combustion system

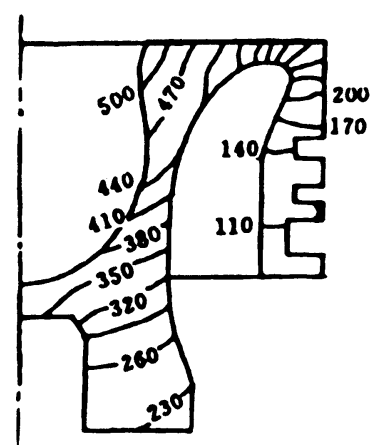

Fig.3 Piston temperature field

い鉄ピストンヘッドとアルミピストンスカートを 組み合わせたピストンは，断熱設計により，燃焼 室の壁面温度を高くして, 植物油の蒸発速度を高 めた，有限要素法により計算したピストンヘッド の温度場は図3に示される。ピストンリング個所と 燃焼室の間には弾性があり，ピストンリング個所 の温度が低く，ピストンとシリンダーの熱膨張が 大体同量なので，ピストンとシリンダーの隙間を シリンダー直径の千分の 1 位に小さく設計してあ り，この部分への炭化物の付着蓄積及び焦げ付き を防止できる.

4）冷却系についてこの機関は冷却水の代 わりに，オイルを使用して，ピストンの下部を噴 油冷却し，シリンダーヘッドとシリンダーブロッ クにはオイル通路によって, 高温冷却を実現した。 冷却油は機関からの出口温度が $100-110^{\circ} \mathrm{C}$ で，機 外の熱交換器で二次冷却される。冷却系は機関部 品の高温部だけを冷却するように設計されている。 

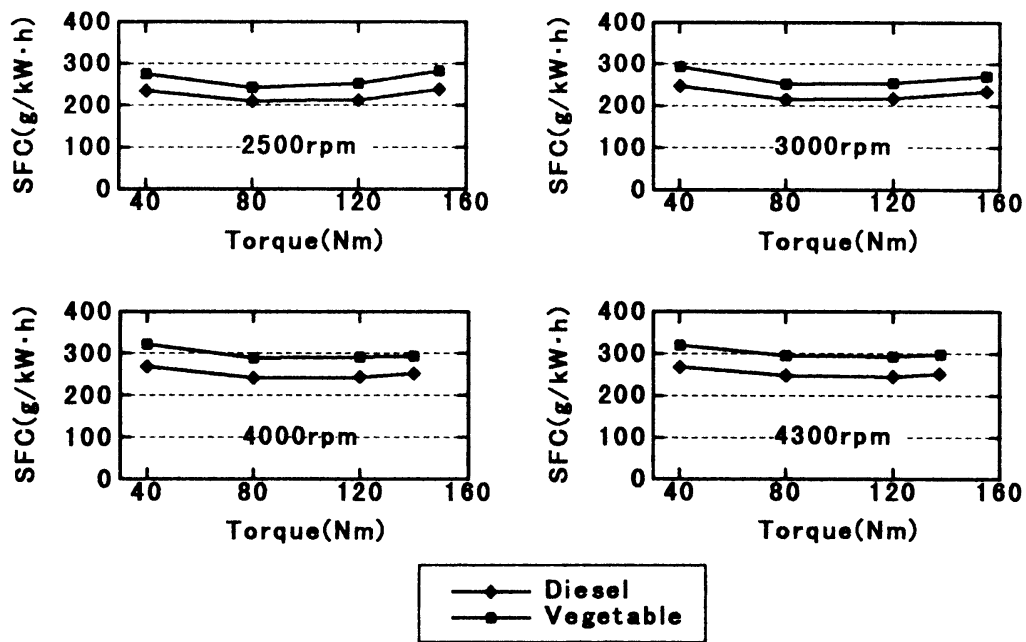

Fig.4 SFC of diesel fuel oil and vegetable oil

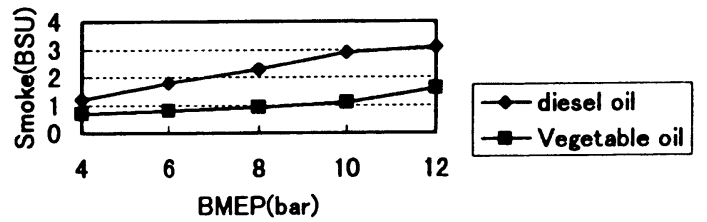

Fig.5 Smoke level of diesel fuel oil and vegetable oil

\section{4. 軽油と植物油を使用した場合の ディーゼル機関の性能}

軽油と植物油を使用した場合の機関性能を調べ た。図4には機関トルクと燃料消費率の関係を示 す。その結果から次のことが得られた。

1）機関の動力性能（トルク, 出力及び回転数 など）はほとんど変わらない。

2) 植物油の燃料消費率は軽油より平均 $15 \%$ 高 い.しかし，植物油の低位発熱量は軽油より $14 \%$ 低いため，機関の効率はおおむね同じである.

3）植物油の密度は軽油より $9 \%$ 高いので，体積 燃料消費量の差異が小さくなる。この機関に駆動 された車の $100 \mathrm{~km}$ 当たりの燃料消費量は, 植物油 が $6.1 \mathrm{~L} て ゙$, 軽油が5.6Lである。

4）植物油は酸素を $11 \%$ 含む燃料で，着火性能 は軽油より悪化するものの, 一旦着火すれば, 酸 素を自分で供給する効果があるため, 燃焼速度は 軽油より速く，すすの排出が少ない。罒5に，軸 平均有効圧と排出すす濃度との関係を示す。
5. 結

論

一部構造を改造した機関に軽油と植物油を使用 した実験結果から，以下のことが明らかとなった。 1）植物油は再生可能な生物エネルギーの一種で, 物性が軽油と似ているため, 内燃機関用の代用燃 料油として使えば，良好は機関性能が得られる。

2）植物性燃料油の使用による機関性能への悪影 響は，植物油の処理や機関構造の改良にしたがっ て抑えられ，植物油を使用する機関の性能を改善 できる。

3）この特別に設計した直接噴射式高速ディーゼ ル機関 (382TC型) は軽油と植物油共に良好な機 関総合性能を持っている。軽油を使用した場合に 比較して，植物油の場合は燃料消費率がわずかに 高いが，熱効率はおおむね同じで，さらに排出す すの濃度が少ない.

本研究にご指導とご助言を頂いた江蘇理工大学高 宗英名誉教授に深く感謝の意を表します。また本 研究は，ドイッのエスベト研究所との共同で行わ れたものである.

\section{参考文献}

1. Breuer,C.Fuel.Vol.74 (1995), No.12 1767 1771.

2. Elsbett,K.et al,SAE Paper 890134 (1989), 1 7. 